\title{
Competitive Strategy, Market Entry Mode and International Performance: The Case of Construction Firms in China
}

\author{
Yan Shigang ${ }^{1}$, Liu Guozhi ${ }^{2}$ \\ ${ }^{1}$ Associate Professor, College of International Economics, China Foreign Affairs University, Beijing, P. R. China \\ ${ }^{2}$ Managing Director, Alpine Mayreder Construction Co., Ltd, Beijing, P. R. China \\ Correspondence: Yan Shigang, Associate Professor, College of International Economics, China Foreign Affairs \\ University, Beijing, P. R. China.
}

Received: November 20, 2016

Accepted: December 23, 2016

Online Published: January 3, 2017

doi:10.11114/bms.v3i1.1999

URL: http://dx.doi.org/10.11114/bms.v3i1.1999

\begin{abstract}
As an important participant in the international construction market, Chinese construction firms (CCFs) are confronted with the tasks of keeping themselves competitive. To help CCFs maintain and improve their competitiveness, this research builds a conceptual model to investigate the relationship between competitive strategy, market entry mode and performance within CCFs. Based on data collected from CCFs, this research has confirmed the importance of cost leadership strategy, differentiation strategy and business scope diversification, to achieve their superior performance. Moreover, there are positive relationships among entry mode strategies with CCFs' international performance.
\end{abstract}

Keywords: construction firms, China, competitive strategy, market entry, international performance

\section{Introduction}

Facing an era of unprecedented business environmental change and uncertainty under the trend of global economic integration, the issues of strategic management and internationalization have become imperative for top management in organizational survival and success. Many multinational enterprises (MNEs) from advanced industrialized countries (AICs) have demonstrated their ability for internationalization in various industries. As a result, their international competitiveness has been built upon and enhanced (Bradley, 2004). Construction has been one of the most important economic activities during the process of humankind's remaking of natural environments. Construction is driven and affected by the global economy, and it has a worldwide impact. According to the study by Co (2014), the output value of global construction markets will reach US\$1.27 trillion on construction in 2020. Such a huge 'cake' has been luring numerous construction firms all over the world. It is hence no wonder that cross-border transactions of construction business have been steadily increasing, regardless of the turbulence in the global political and economic scene.

China had built up an extensive basic infrastructure during the past three decades. It is expected that the high demand for construction in China will last for a long time in future due to its fast economic growth. According to National Bureau of Statistics of China, the contribution of the construction industry to the GDP of China increased from 5.5\% in 2000 to $7.0 \%$ in 2014 . The gross output value of the construction industry, which was RMB 1249.76 billion in 2000, had reached RMB 17671.34 billion in 2014. The number of people involved in the industry rose from 19.94 million in 2000 to 45.37 million in 2014 (NBS, 2015). The average annual growth rate of the industry has been over $9 \%$ since 2000. With the rapid development of the Chinese construction industry, increasing support from the Chinese government, and "One Belt One Roda" Initiative, Chinese construction firms (CCFs) have been given numerous opportunities in venturing abroad and acquiring wide-ranging experience, enhancing their knowledge and skills. Chinese construction firms (CCFs) have been given great opportunities in venturing abroad and acquiring wide-ranging experience, enhancing their knowledge and skills. Some CCFs have made significant achievements in the global construction market. The number of CCFs that have emerged in the Engineering News Record (ENR) Top 250 International Contractors list has increased from a mere 4 in 1992 to 65 in 2014. The gross contracting revenue of the 65 Chinese contractors reached $\$ 89.55$ billion in 2014 and accounted for $17.17 \%$ of the top 250 contractor's revernue (ENR, 2015).

The rapid emergence of CCFs in international markets has generated much interest in their competitors around the globe as well as in researchers (Cheah et al., 2007; Chen \&Orr, 2014; Co, 2014). Despite the sharp increase in the 
number of CCFs in recent years, the average revenue generated by each firm is far less than their counterparts from the advanced countries (Wu et al., 2008). As latecomers to the international market, the appropriate strategic selection of international construction market thus becomes important for CCFs. However, based on extensive literature review, it was found that there are few empirical studies on how to improve CCFs' international performance, especially from the corporate perspectives. The purpose of this study is to understand the determinants of CCFs. Drawing on the industrial organization approach and market entry mode view, the study focuses on investigating the competitive strategy and market entry mode affecting CCFs' international performance.

\section{Literature Review}

The trend towards globalisation has added a new dimension into the field of strategy (De Wit \& Meyer, 2005). Researchers have presented various conceptual models based on profound theories to explore the factors that may influence the process of internationalization and the choice of entry mode in foreign markets (Dunning, 1988; Porter, 1990; Anderson, 1997; Madhok, 1997; Sharma \& Blomstermo, 2004; Santangelo \& Meyer, 2009; Wilson \& Baack, 2012; Anderson et al., 2014). Porter (1990) produced a critique on comparative advantage and proposed alternative concepts of competitive advantage - the "National Diamond". The Diamond framework highlights not only the naturally inherited or comparative but also the advanced or competitive factors of production. Dunning (1988) explained the prerequisites of the existence of MNE by providing an eclectic theory, i.e. ownership-specific advantage, location-specific advantage and internalization-specific advantage (OLI) based on the previous MNE theories. The international strategic management studies employed or referenced the RBV has increased significantly since 1990s (Barney, 1991; Makadok, 2001). The presence of resources and capabilities could provide a firm the discretion or motivation (strategic choices) to pursue a strategy of internationalization thereby increasing its size and profitability (Knight \& Kim, 2009).

In the study of the competitive advantages developed by CCFs, this research will acknowledge that industrial organization approach and market entry mode have their impact on CCFs' performance. Industrial organization approach examines the impact of firm's competitive behavior and performance at the industry level. Porter (1980) adapted this paradigm to strategic management and examined existing firm's strategic decision to enter a new business. Porter identified factors that prevail in any industry, such as product differentiation, economies of scale, economies of scope, organizational learning, etc. These factors present threats and opportunities for gaining and creating competitive advantage and in turn superior performance. In construction management literature, researchers explored competitive positioning and its performance implications in the context of the construction industry (Kale \& Arditi, 2002; Cheah et al., 2007; David et al., 2008; Langford \& Male, 2008; Co, 2014). Kale \& Arditi (2002) stated successful construction companies should place varying degrees of emphasis on more than one mode of competition, such as cost, quality, innovation, and time. David et al. (2008) confirmed the applicability of competitive strategy, which included cost, quality and delivery, to achieve competitiveness for Chinese contractors. In the international context, CCFs have made significant progress in building up their competitiveness in recent years and become competitors to other overseas contractors in international construction markets (Zhao \& Shen, 2008). Chinese contractors adopted competitive strategies especially in changing environment in order to achieve sustainable growth and profitability (Kallia, 2012). Wu et al. (2008) analyed the prevailing process of internationalization of top Chinese constractors and provided a strategic direction for their international construction market selection. Parsa et al. (2015) stated that Chinese construction firms continued to improve their international competitiveness by adopting competitive strategies in the international construction markets.

Market entry strategies are one of the most important international business strategies. The selection of an appropriate entry mode is crucial and affects the overall success of an investment (Porter, 1989; Woodcock et al., 1994). Through the internationalisation process, firms gradually expand their business activities beyond their national authority and launch operations in other countries (Ahmad \& Kitchen, 2008). To expand its activities to an international market, a firm must adapt an appropriate form of entry that determines the firm's performance and survival in foreign markets (Pan \& Tse, 2000). The selection of an appropriate entry mode is crucial and affects the overall success of an investment. According to Pan \& Tse (2000), entry modes can be viewed as two major categories: equity-based modes (wholly-owned subsidiaries and equity joint ventures (EJVs) and non-equity-based modes (contractual agreements and export). Not all entry modes are suitable to any firms. The mode of entry decision reflects the level of commitment to and investment by the firm in international markets (Bradley, 2004). For different market entry modes, the resource commitment should be different, and the firms will possess different control power, but they have to face different level of risks. Generally, the greater the resource commitment, the higher the risk, but also the more control the firm has over its international operation. 


\section{Research Hypotheses}

With the globalization of the world economy, construction markets in most countries are gradually opening up to foreign contractors. International contractors from different countries tend to adopt different strategies to compete internationally. To achieve success in the international construction market, CCFs need to upgrade their organizational strategies through operations in new countries and markets. The framework presented here is based on earlier frameworks that were proposed or adopted in previous studies (Cheah et al., 2007; Chen \& Orr, 2014; Kallia, 2012). It proposes that construction firms' performance is critically dependent on their competitive strategy and market entry mode. Competitive strategy determines the relative competitive position and performance of CCFs in the international construction market. CCFs have to select suitable modes to enter foreign markets based on the environmental conditions and firms' internal factors, and market entry mode has direct impacts on CCFs' international performance.

\subsection{Competitive Strategy and International Performance}

The business environment within international construction market is very volatile. Competition from new entrants, social reforms, technological advancement and globalization pose major challenges of growth of this industry. Carpano et al. (1994) studied generic competitive strategies in the international context from two major dimensions: segment differentiation and geographical scope. They also highlighted the importance of cost leadership and differentiation strategies. Pheng et al. (2004) suggested that the relatively low cost of construction machinery, material and equipment from China facilitates the reduction of the bidding price for CCFs. Kallia (2012) focused on the competitive strategies adopted by Chinese contractors in Kenya and stated that the most practiced competitive strategies by Chinese adopted were cost leadership and difference strategy. Parsa et al. (2015) found that the international competitiveness of CCFs continued to improve due to relatively low costs and resulting competitive bidding prices. Thus, it is expected CCFs to have a broader range of possible actions and to rely heavily on developing competitive strategy in order to be sustainable in the international construction market.

\subsubsection{Cost Leadership Strategy and International Performance}

A cost leadership strategy requires management to focus its attention on competing on cost (Male \& Stocks, 1991). Cost advantage leads to superior performance if the firm provides an acceptable level of value to the client so that its cost advantage is not nullified by the need to charge a lower price than competitors (Porter, 1985). The firm sells its products either at average industry prices to earn a profit higher than that of rivals, or below the average industry prices to gain market share. According to Porter (1985), preferential access to raw materials, proprietary technology, and economies of scale or scope represent potentially significant competitive advantages. These represent sources of cost advantage and make the firm to be the low-cost leader in its industry. CCFs have obvious advantage on labour costs, material and equipment costs and overhead, as compared to their competitors from AICs. As Wu et al. (2008) commented, CCFs have been successfully competing in international markets based mainly on cost leadership strategy. Therefore, although cost leadership may not be effective for CCFs in the home market, it may be effective in international markets when competing with contractors from AICs. Thus the first hypothesis is:

\section{$H_{1.1}$ : Cost leadership strategy is positively related to CCFs' international performance.}

\subsubsection{Differentiation Strategy and International Performance}

The differentiation strategy implies that a firm offers something unique and unmatched by its competitors and valued by the industry that enables the firm to command higher prices than industry average (Male \& Stocks,1991). Differentiation strategy calls for creating and developing something truly unique or that is perceived as unique in order to achieve and sustain competitive advantage. In construction industry, contractors using this competition strategy aim to outperform their rivals through providing their clients with more values. Many Chinese researchers suggested CCFs to adopt differentiation strategy in international markets (Wu et al., 2008). In particular, CCFs have achieved good international performance by pursuing differentiation strategy, coupled with cost leadership (Kallia, 2012). Thus, differentiation strategy could play an important role in improving CCF's international performance.

\section{$H_{1.2}$ : Differentiation strategy is positively related to $C C F s^{\prime}$ international performance.}

\subsubsection{Geographical Scope Diversification and International Performance}

Focusing on a market segment enables a firm to gain exclusive experience of the conditions and trends within that market segment which in turn increases its responsiveness. Therefore, adopting a narrow market approach to compete in the context of international construction presents some potential for creating superior performance. On the other hand, by adopting a broad market approach, contractors can exploit economies of scale and scope by sharing the resources in different locations, spreading the risks across different markets and significantly reducing their vulnerability against market fluctuations. As Gunhan (2003) indicated, expanding business into new geographical areas will help to establish new networks and improve the firm's track record. Hence, adopting a broad market approach for competition also 
presents some potential for creating superior performance. Many Chinese researchers suggested that CCFs should widen their geographical coverage gradually. They argued that the narrow market approach is usually more suitable during the early venturing stage and for small and medium sized enterprises (SMEs) with limited resources whereas the broad market approach is more appropriate for the developed stage and large CCFs (Wu et al., 2008; Chen \& Orr,2014). As this study focuses on large CCFs, the broad market approach is supposed to influence the international performance of CCFs, therefore:

\section{$H_{1.3}$ Geographical scope diversification is positively related to $C C F s^{\prime}$ international performance.}

\subsubsection{Business Scope Diversification and International Performance}

Business scope diversification involves both horizontal diversification (into different products and services) and vertical integration (along a value system/vertical market). One possible reason for construction firms pursuing a horizontal diversification strategy is that there is a need to spread risks and reduce fluctuations in revenues, which may be seasonal or cyclical, as suggested by the portfolio theory (Hillebrandt \& Cannon, 1989). Another possible reason for pursuing horizontal diversification is to fully create synergies among operating and management activities. Two major reasons for pursuing the vertical integration strategy are reducing operational uncertainty and increasing profitability. Adopting a broad product/service approach enables CCFs to share their resources in different foreign projects. The synergy among these resources can lead to cost reductions and enhance revenue and hence improve their international performance. Therefore, this study supposes that business scope diversification is helpful for the international performance of CCFs. Based on the above discussions, the fourth hypothsis is made as follows:

$H_{1.4}$ : Business scope diversification is positively related to $C C F s^{\prime}$ international performance.

\subsection{Market Entry Strategy}

It is an ambitious task to link market entry strategies with their influence on subsequent performance. Gunhan (2003) stated that some entry modes provided better performance than other modes. Anand \& Delios (1997) showed that market entry strategy could have important implications for firm's performance. Specifically, it was found that the comparative performance of the three entry modes - wholly-owned subsidiary, joint venture (JV) and merger and acquisition (M\&A) was contingent on the industry of entry and the associated demands for local content.

Chen \& $\mathrm{Hu}(2002)$ revealed that wholly-owned subsidiaries are more likely to be chosen than EJVs when MNEs expand into markets with high regional and industrial growth; and they are also more likely to be chosen than CJVs when the investments involve proprietary products or where the cultural distance is large between the home and host country markets. Pan \& Chi (1999) revealed that MNEs using wholly-owned subsidiary and EJVs to enter into China achieved better financial performance than those employing CJVs. JV means that all rights and obligations, risks and returns are shared according to equity contributions or the JV contract (Chen \& Hu, 2002). CCFs adopting JVs benefit from savings in production costs, risk sharing with local partners, acquiring knowledge of host markets, and securing future growth opportunities. Sophisticated contracting has become one of the significant trends of international construction. The sophistication level of contracting modes directly influences the rivalry intensity among international construction participants (Leiringer, 2006). Sophisticated contracting modes set higher entry barriers for participants in track records, financing, technological and management capability.

Based on the above analysis, each entry mode has ample scope for application. The impacts of wholly-owned subsidiary, $\mathrm{JV}$ and sophisticated contracting strategies on firm's performance are hypothesized as follows:

$H_{2.1}:$ Wholly-owned subsidiary strategy is positively related to CCFs' international performance.

$H_{2.2}: \mathrm{JV}$ strategy is positively related to CCFs' international performance.

$H_{2.3}$ : Sophisticated contracting strategy is positively related to $C C F s^{\prime}$ international performance.

\section{Research Methodology}

\subsection{The Sample and Survey Instrument}

The survey method used is a structured questionnaire. The original English questionnaire was first reviewed and revised by two professors (one in engineering management and another in strategic management) with substantial research experience in the subject area in China and then translated into Chinese. The questionnaire survey targeted large CCFs which were undertaking international construction projects. The sample was selected based on the ranking of the firms in the ENR Top 250 International Contractors list and their reputation in China. The questionnaire, together with a cover letter explaining the methodology and objective of the study, was distributed to fifteen CCFs by mail. Altogether 260 sets of questionnaire were sent out, and a total of 92 sets of answered questionnaires were received. The rate of return is $35.4 \%$. 
The general information of the respondents is summarized in Table 1. Among these respondents, 37 were from top management, and 55 were department managers and project managers. There were 48 respondents from civil engineering firms and 44 from general building firms. Most of the respondents were from HQs, whereas 28 were from their subsidiaries which were involved in international construction. All respondents were experienced and well familiar with the research area. After sending out the questionnaire, further contacts through email and telephone were also made to confirm and probe further several respondents' views if such respondents had provided contact information in the returned questionnaire.

Table 1. General information of the respondents

\begin{tabular}{llll}
\hline & & & Number of respondents \\
\hline Classified & \multirow{2}{*}{$\begin{array}{lll}\text { Designation } \\
\end{array}$} & President/general manager//director & 37 \\
& & Department manager/project manager & 55 \\
& Total & $\mathbf{9 2}$ \\
Classified by CCFs' & Civil engineering & HQ & 35 \\
Business Nature & & Subsidiary & 13 \\
& General building & HQ & 29 \\
& Total & Subsidiary & 15 \\
\hline
\end{tabular}

Source: Developed by the author

\subsection{Measurement}

Most of the factors in the questionnaire are self-developed to suit the practice in the industry. The instrument has been tested for face-to-face validity on contractors. All key variables in the study were assessed using multiple measures. Such measures are necessary to capture the domain of the constructs adequately and accurately (Churchill, 1979; Nunnally, 1978). In addition, this approach is believed to reduce measurement error and increase the reliability and validity of the measures (Churchill, 1979).

The competitive strategy variables were measured using five-point Likert scales ranging from 1 "not at all important" to 5 "extremely important". Cost leadership strategy included six items: (1) labour cost, (2) material and equipment cost, (3) overhead cost, (4) project and operational cost control, (5) ability to access low-cost resources, and (6) economies of scale or scope. Differentiation strategy could be measured and developed in five areas: (1) quality, (2) delivery time, (3) tractive financing packages, (4) good relationship with external parties, and (5) technology and innovation.

\subsection{Firm's Performance}

The performance was often measured by the business volume (including sales, profit) (David, et al., 2008), efficiency (productivity, return on equity) (Davies \& Walters, 2004), and the overall performance (Kale \& Arditi, 2002). The overall performance can be measured by a multi -dimensional method or by averaging the sales growth and profit growth. This research adopted the latter, which means that the sales growth and profit growth were treated as equally important for the international performance of CCFs.

\section{Analysis and Results}

\subsection{Reliability Analysis}

The reliability of data is the basis of the quality of research findings. The internal consistency of scales is usually assessed by the Cronbach Alpha method. Cronbach's coefficient alpha was used to measure the degree of covariation among competitive strategy and market entry strategies variables. Cronbach Alpha values for the research variables of these constructs, which indicated that all survey data are basically reliable. The resulting values range from 0.59 to 0.62 , indicating an acceptable level of internal consistency (Churchill, 1979; Nunnally, 1978).

\subsection{Research Findings}

Regression analysis is used to determine the degree to which selected independent variables were able to predict Chinese CCFs. The measure of "overall performance" is given by the average of sales and profit growth rates.

\subsubsection{Competitive Strategy and International Performance}

As indicated in table 2 , these three related models are all statistically significant at 0.01 level. The values of adjusted $\mathrm{R}^{2}$ for Model 1a, $1 \mathrm{~b}$ and $1 \mathrm{c}$ are $0.46,0.38$ and 0.57 respectively. It means that these four generic competitive strategy variables can explain $46 \%, 38 \%$ and $57 \%$ of the variance in the sales growth, profit growth and overall performance of CCFs. These values are deemed to be acceptable for evaluating these three models, compared to previous studies.

The results showed that cost leadership strategy has significantly positive relationship with overall performance with a coefficient of 0.37 at 0.01 levels, indicating that $\mathrm{H}_{1.1}$ is supported. Differentiation strategy had significantly positive relationship with international performance with coefficients of 0.30 at 0.01 level, Thus $\mathrm{H}_{1.2}$ is supported. Geographical 
scope diversification has no significantly positive relationship with any of the three performance variables at 0.1 level of significance, $\mathrm{H}_{1.3}$ was not supported. The regression coefficients of business scope diversification were statistically significant to sale growth $(\beta=0.22, \mathrm{p}<0.05)$ and overall performance $(\beta=0.16, \mathrm{p}<0.10)$. Thus $\mathrm{H}_{1.4}$ was supported.

Table 2. Regression coefficients for competitive strategy and international performance

\begin{tabular}{lccc}
\hline Competitive strategy & $\begin{array}{c}\text { Sales growth } \\
\text { (Model 1a) }\end{array}$ & $\begin{array}{l}\text { Profit growth } \\
\text { (Model 1b) }\end{array}$ & $\begin{array}{l}\text { Overall performance } \\
\text { (Model 1c) }\end{array}$ \\
\hline Cost leadership & $0.30^{* * *}$ & $0.34^{* * * *}$ & $0.37^{* * *}$ \\
Differentiation & $0.21^{*}$ & $0.31^{* * *}$ & $0.30^{* * *}$ \\
Geographical scope diversification & 0.14 & 0.06 & 0.12 \\
Business scope diversification & $0.22^{* *}$ & 0.04 & $0.16^{*}$ \\
\hline Adjusted $\mathrm{R}^{2}$ & 0.46 & 0.38 & 0.57 \\
F-Value & $19.97^{* * *}$ & $15.05^{* * *}$ & $31.48^{* * *}$ \\
\hline
\end{tabular}

${ }^{*} \mathrm{P} \leq 0.1 ;{ }^{\text {*** }} \mathrm{P} \leq 0.05 ;{ }^{* * * *} \mathrm{P} \leq 0.01$

5.2.2 Market Entry Mode and International Performance

As indicated in table 3 , all these three related models are all statistically significant at 0.01 level. The values of adjusted $\mathrm{R}^{2}$ for Model $2 \mathrm{a}, 2 \mathrm{~b}$ and $2 \mathrm{c}$ are $0.36,0.27$ and 0.39 respectively, which are deemed acceptable for evaluating these three models. It implies that these three market entry strategy variables can explain 36\%, 27\% and 39\% of the variance in the sales growth, profit growth and overall performance of CCFs.

The results showed that wholly-owned subsidiary has had a significantly positive relationship with both profit growth $(\beta=0.41, p<0.01)$ and overall performance $(\beta=0.31, p<0.01)$. Hence, $H_{2.1}$ was supported. The regression coefficients of JV strategy variable had a significantly positive relationship with both sales growth $(\beta=0.39 \mathrm{p}<0.01)$ and overall performance $(\beta=0.31, \mathrm{p}<0.01)$. Thus, $\mathrm{H}_{2.2}$ was also supported. The results showed that sophisticated contracting had a significantly positive relationship with all the three performance variables: sales growth $(\beta=0.34, \mathrm{p}<0.01)$, profit growth $(\beta=0.21, p<0.05)$, and overall performance $(\beta=0.33, \mathrm{p}<0.01)$. Therefore, $\mathrm{H}_{2.3}$ was strongly supported.

Table 3. Regression coefficients for market entry mode and international performance

\begin{tabular}{lccc}
\hline Market entry mode & $\begin{array}{l}\text { Sales growth } \\
\text { (Model 2a) }\end{array}$ & $\begin{array}{l}\text { Profit growth } \\
\text { (Model 2b) }\end{array}$ & $\begin{array}{l}\text { Overall performance } \\
\text { (Model 2c) }\end{array}$ \\
\hline Wholly-owned subsidiary & 0.14 & $0.41^{* * *}$ & $0.31^{* * *}$ \\
JV & $0.39^{* * *}$ & 0.13 & $0.31^{* * *}$ \\
Sophisticated contracting & $0.34^{* * *}$ & $0.21^{* *}$ & $0.33^{* * *}$ \\
\hline Adjusted $\mathrm{R}^{2}$ & 0.36 & 0.27 & 0.39 \\
F-Value & $17.78^{* * *}$ & $12.14^{* * * *}$ & $20.51^{* * *}$ \\
\hline
\end{tabular}

${ }^{*} \mathrm{P} \leq 0.1 ;{ }^{* *} \mathrm{P} \leq 0.05 ;{ }^{* * *} \mathrm{P} \leq 0.01$

5.3 Discussion of the Findings

As indicated in the analytical results, cost leadership and differentiation strategies directly contributed to the international performance of CCFs in term of sales growth and profit growth. When CCFs compete at the international level, their major competitors are foreign contractors, particularly those from AIC, CCFs have comparative cost advantage as compared to their competitors from AICs. However, they tended to lag behind their competitors in technological, financial and management aspects. Hence, they will require their cost advantage to offset these disadvantages. At the same time, a number of large CCFs had already accumulated much experience in executing large, complex projects both at home and in international markets, which enabled them to adopt differentiation strategy. Besides, they could also differentiate themselves from the AIC competitors in other aspects. Externally, international competition has become increasingly intense, with contracting modes becoming more complicated. This necessitates all participants to position themselves differently to increase their winning chances and remain competitive, as pure reliance on cost advantage is no longer relevant in this market environment.

In addition to cost leadership and differentiation strategies, the analytical results also revealed that business scope diversification contributed to the international performance of CCFs in terms of sales growth. The business scope of these CCFs in China is broad, covering a wide range of construction and related businesses. Business scope 
diversification in international markets can enable them to effectively employ their human resources and specialised construction equipment at home. However, as business scope diversification usually requires firms to increase or re-allocate resources, firm's performance in profitability could be affected, especially at the early stage. Due to the short history of CCFs' international operation, the financial benefits accruing from this strategy had yet to be realized. The positive relationship between geographical scope diversification and international performance was not supported by the results. The insufficient international exposure and high entry barriers in many countries increased CCFs' costs of initial entry to such countries, thereby hindered their geographical expansion. The disadvantageous financial and technological capabilities of CCFs still posed as bottlenecks in their geographical expansion.

Using the wholly-owned subsidiary approach, CCFs could fully utilize their cost advantage and hence achieved better financial performance. However, due to their lack of international exposure, wholly-owned subsidiary would further limit their international networking compared to the pursuit of JV strategy, thus undermining their international competitiveness. This could be the reason why wholly-owned subsidiary approach failed to help increase their sales volume. JV strategy helped CCFs achieve good sales growth, but was unable to help them increase their profits. This result indicated that even though CCFs were confident in sole operation in traditional markets, they still needed to cooperate with foreign firms. Cooperating with local contractors might enable CCFs to make full use of the locational advantages. Sophisticated contracting strategy contributed to CCFs' sales growth and profit growth. The locational and cultural proximity enabled large CCFs to implement large, complicated projects in their traditional markets. Sophisticated contracting reduced the intensity of rivalry thus increasing profits, and enabled CCFs to offer unique service packages to increase client's value, which was also benefit to themselves.

\section{Conclusions}

This study has taken a step toward delineating the dimensions of competitive strategy and market entry mode adopted by construction firms through comprehensive literature and preliminary interviews. The CCFs' competitive strategy could be characterized by four dimensions: cost leadership strategy, differentiation strategy, geographical scope diversification and business scope diversification. The entry mode strategies covered wholly-owned subsidiary, JV and sophisticated contracting strategies. Based on data collected from CCFS in China, this study has confirmed the importance of competitive strategies, including cost leadership strategy, differentiation strategy and business scope diversification, to achieve their superior performance. Moreover, there are positive relationships among entry mode strategies with CCFs' international performance.

The findings of this study also have implications for management practice. Specifically, the result of this research may be useful for management practitioners who are involved in the development of CCFs. Top management of CCFs should also pay more attention to the interaction of the generic competitive strategies and market entry strategies. For example, CCFs could first partner with their foreign counterparts to undertake projects in China. Upon building up their mutual trust and relationship, CCFs could seek the reciprocal assistance from their foreign partners to venture into their home or third country markets. Besides, forming JVs with foreign contractors specialized in different project segments could also be a good channel for CCFs to diversify their business scope. In this way, the initial investment and attendant risk arising from unfamiliarity for such projects would be minimized. Thus the flexible application of a portfolio of strategies could be an avenue for future success of CCFs in international markets.

There are some limitations in terms of the scope of this research, which lead to the recommendations for others to research in future. This research focuses on large CCFs and in particular SOEs. However, the number of large private CCFs has been increasing. Private CCFs are very active in the home market. They have evident advantages in numerous aspects, such as a more flexible management system and progressive corporate culture over SOEs. Thus, the study of private CCFs warrants future research. The hypothesis testing results were based on the current status of CCFs and their international performance for the past three years. Due to the dynamic nature of the measures for the research variables, future research is required to constantly update the conceptual model to reflect the new circumstances when situation changes. In this study, only the selected market entry strategies were studied. Other entry modes could also become more important to CCFs, such as M\&A. Western contractors have been treating M\&A as an important entry mode. A number of large CCFs have also executed M\&As within Chinese enterprises over the past few years. This phenomenon tends to continue under the guidance of the Chinese government. Thus, M\&A strategy should be considered in future research.

In summary, this research provides overall guidelines for CCFs to understand their international strategic position and external environments, to know the major international strategic management aspects to be emphasized, and what strategies are critical for improving their international performance. Corporate managers of CCFs should take further actions to formulate concrete strategies from a long-term strategic management perspective, by considering these guidelines, other strategic management knowledge, and their firms' specific status. 


\section{References}

Ahmad, S. Z., \& Kitchen, P. J. (2008). International expansion strategies of Malaysian construction firms: entry mode choice and motives for investment. Problems and Perspectives in Management, 6(3), 15-23.

Anand, J., \& Delios, A. (1997) . Location specificity and the transferability of downstream assets to foreign subsidiaries. Journal of International Business Studies, 28(3), 579-603. https://doi.org/10.1057/palgrave.jibs.8490112

Andersen, O. (1997). Internationalization and market entry mode: A review of theories and conceptual framework. Management International Review, 37(2), 27-42.

Andersen, P., Ahmad, S. Z., \& Chan, W. M. (2014). Revisiting the theories of internationalization and foreign market entry mode: A critical review. International Journal of Business \& Commerce, 4(4), 37-86.

Barney, J. B. (1991). Firm resources and sustained competitive advantage. Journal of Management, 17, 99-120. https://doi.org/10.1177/014920639101700108

Bradley, F. (2004). International marketing strategy, $4^{\text {th }}$ ed., New Jersey, NJ: Prentice Hall.

Carpano, C., Chrisman, J. J., \& Roth, K. (1994). International strategy and environment: An assessment of the performance relationship. Journal of International Business Studies, 25(3), 639-656. https://doi.org/10.1057/palgrave.jibs.8490216

Cheah, C. Y. J., Kang, J., \& Chew, D. A. S. (2007). Strategic analysis of large local construction companies in China. Construction Management and Economics, 25(1), 25-38. https://doi.org/10.1080/01446190600693450

Chen, H., \& Hu, M. Y. (2002). An analysis of determinants of entry mode and its impact on performance. International Business Review, 11, 193-210. https://doi.org/10.1016/S0969-5931(01)00055-5

Chen, C., \& Orr, R. J. (2014). Chinese contractors in Africa: home government support, coordination mechanisms and market entry strategies. Journal of Construction Engineering and Management, 135(11), 1201-1210. https://doi.org/10.1061/(ASCE)CO.1943-7862.0000082

Churchill, G. A. (1979). A paradigm for developing better measures of marketing constructs. Journal of Marketing Research, 16, 64-73. https://doi.org/10.2307/3150876

Co, C. Y. (2014). Chinese contractors in developing countries.Review of World Economics, 150(1), $149-171$. https://doi.org/10.1007/s10290-013-0170-5

David, C., Yan, S., \& Charles, Y. J. (2008). Core capability and competitive strategy for construction SMEs in China. Chinese Management Studies, 2(3), 203-221. https://doi.org/10.1108/17506140810895898

Davies, H., \& Walters, P. (2004). Emergent patterns of strategy environment and performance in a transition economy. Strategic Management Journal, 25, 347-364. https://doi.org/10.1002/smj.380

De Wit, B., \& Meyer, R. (2005). Strategy Synthesis: Resolving Strategy Paradoxes to Create Competitive Advantage, 2nd ed., London: Thomson Learning.

Dunning, J. H. (1988). The eclectic paradigm of international production: a restatement and some possible extensions. Journal of International Business Studies, 19(1), 1-31. https://doi.org/10.1057/palgrave.jibs.8490372

Engineering News Record (ENR) (2015). The top 225 international contractors. http://www.enr.com/toplists/2015_Top_250_International_Contractors(July 10, 2016)

Gunhan, S. (2003). Foreign market entry decision model for construction companies. PhD thesis, Illinois Institute of Technology, USA

Hillebrandth, P. M., \& Canon, J. (1989). The Management of Construction Firms: Aspects of Theory, UK, London: Palgrave Macmillan. https://doi.org/10.1007/978-1-349-13626-1

Kale, S., \& Arditi, D. (2002). Competitive positioning in United States construction industry. Journal of Construction Engineering and Management, 128(3), 238-247. https://doi.org/10.1061/(ASCE)0733-9364(2002)128:3(238)

Kallia, M. A. (2012). Competitive strategies adopted by Chinese firms in the building and construction industry in Kenya, PhD thesis, University of Nairobl.

Knight, G. A., \& Kim, D. (2009). International business competence and the contemporary firm. Journal of International Business Studies, 40(2), 255-273. https://doi.org/10.1057/palgrave.jibs.8400397

Langford, D., \& Male, S. (2008). Strategic management in construction. Oxford: Blackwell Science.

Leiringer, R. (2006). Technological Innovation in PPPs: Incentives, opportunities and actions", Construction 
Management \& Economics, 24(3), 301-308. https://doi.org/10.1080/01446190500435028

Madhok, A. (1997). Cost, value and foreign market entry mode: The transaction and the firm. Strategic Management Journal, 18(1), 39-61. https://doi.org/10.1002/(SICI)1097-0266(199701)18:1<39::AID-SMJ841>3.0.CO;2-J

Makadok, R. (2001). Toward a synthesis of the resource-based and dynamic-capability views of rent creation. Strategic Management Journal, 22(5), 387-401. https://doi.org/10.1002/smj.158

Male, S., \& Stocks, R. (1991). Competitive Advantage in Construction. Oxford: Butterworth Heinemann.

National Bureau of Statistics of China (2015). China Statistical Yearbook on Construction. Beijing: State Statistics Bureau Press.

Nunnally, J. C. (1978). Psychometric theory, New York, NY: McGraw-Hill.

Pan, Y., \& Chi, S. K. (1999) .Financial performance and survival of multinational corporations in China. Strategic $\begin{array}{lll}\text { Management } \quad \text { Journal, } & \text { 359-374), }\end{array}$ https://doi.org/10.1002/(SICI)1097-0266(199904)20:4<359::AID-SMJ31>3.0.CO;2-9

Pan, Y., \& Tse, D. K. (2000).The hierarchical model of market entry modes. Journal of International Business Studies, 31(4), 535-554. https://doi.org/10.1057/palgrave.jibs.8490921

Parsa, A., Huston, S., Kashyap, A., \& Li, P. (2015). The international competitiveness of Chinese construction firms, European Real Estate Society (ERES) Conference, 24-27th June, 2015, Istanbul, Turkey.

Pheng, L. S., Jiang, H. B., \& Christopher, H. Y. L. (2004). A comparative study of top British and Chinese international contractors in the global market. Construction Management and Economics, 22, 717-731. https://doi.org/10.1080/0144619042000202780

Porter, M. E. (1980). Competitive Strategy: Techniques for Analysing Industries and Competitors, New York, NY: Free Press.

Porter, M. E. (1985) .The Competitive Advantage. New York , NY: Free Press.

Porter, M. E. (1989). From competitive advantage to corporate strategy. Harvard Business Review, 5(5), 43-59. https://doi.org/10.1007/978-1-349-20317-8_17

Porter, M. E. (1990). The Competitive Advantage of Nations. London: Macmillan. https://doi.org/10.1007/978-1-349-11336-1

Santangelo, G. D., \& Meyer, K. E. (2011). Extending the internationalization process model: Increases and decreases of MNE commitment in emerging economies. Journal of International Business Studies, 42(7), 894-909. https://doi.org/10.1057/jibs.2011.25

Sharma, D. D., \& Blomstermo, A. (2003). The internationalization process of born global: A network view. International Business Review, 12(6), 739-753. https://doi.org/10.1016/j.ibusrev.2003.05.002

Zhao, Z. Y., \& Shen, L. Y. (2008). Are Chinese contractors competitive in international market? Construction Management and Economics, 26(26), 225-236. https://doi.org/10.1080/01446190801905380

Wilson, R. T., \& Baack, D. W. (2012). Attracting foreign direct investment: Applying Dunning's location advantages framework to FDI advertising. Journal of International Marketing, 20(2), 96-115. https://doi.org/10.1509/jim.11.0023

Woodcock, C. P., Beamish, P. W., \& Makino, S. (1994). Ownership-based entry mode strategies and international performance. Journal of International Business Studies, 25(2), $253-273$. https://doi.org/10.1057/palgrave.jibs.8490200

Wu, W., David, A. S. C., Li, Q., \& Zhong, Y. (2008). Analysis of top Chinese contractors' developmental tracks and evaluation of their strategic selection of internatiOnal construction market. Engineering Science, 6(4), 80-96.

\section{Copyrights}

Copyright for this article is retained by the author(s), with first publication rights granted to the journal.

This is an open-access article distributed under the terms and conditions of the Creative Commons Attribution license which permits unrestricted use, distribution, and reproduction in any medium, provided the original work is properly cited. 